\title{
BIPOLAR TRANSPORT OF CHARGE CARRIERS IN BLENDS OF ORGANIC MATERIALS *
}

\author{
G. Juška, E. Montrimas, J. Sidaravičius, and G. Sliaužys \\ Department of Solid State Electronics, Faculty of Physics, Vilnius University, Saulètekio 9, LT-10222 Vilnius, Lithuania \\ E-mail: gytis.juska@ff.vu.lt
}

Received 21 December 2005

\begin{abstract}
Hole and electron transport in mixtures of donor and acceptor organic molecules bounded by various polymeric materials was investigated by the time-of-flight method. Dependences of electron and hole mobility on electric field, temperature, and layer's composition were measured. Based on the model of charge carrier transport in organic materials of disordered structure, parameters of energy and positional disorder were evaluated.
\end{abstract}

Keywords: organic materials blend, mobility, quantum efficiency

PACS: $78.55 . \mathrm{Kz}, 73.63 .-\mathrm{b}$

\section{Introduction}

Recently, due to possible application in molecular electronics the bipolar charge carrier transport of organic material blends induced great interest. Usually, depending on homogeneous organic material, either electrons or holes are mobile. For effective electrographic photoreceptors or solar cells it is necessary that charge carriers of both signs were mobile. Moreover, recently [1] in blends of organic materials, so called bulk heterojunctions, the photogeneration quantum efficiency has been estimated to be close to unity, while it is much less than one in homogeneous organic materials (caused by Onsager gemini recombination). In blends, due to different pathways for charge carriers of opposite sign, also the bimolecular recombination is much slower than the Langevin recombination typical of low mobility materials [2].

The goal of this research was to investigate peculiarities of charge carrier transport in blends of donor (hole transport material - HTM) and acceptor (electron transport material - ETM) organic molecules with binding polymer (BM).

\section{Experiment}

The mixtures of hole transport material (derivative of stilbene) and electron transport material 2,7-Bis-(1-

\footnotetext{
* The report presented at the 36th Lithuanian National Physics Conference, 16-18 June 2005, Vilnius, Lithuania.
}

phenyl-ethyl)-benzo[lmn][3, 8]phenanthroline-1,3,6, 8tetraone (NTJB1) with different binding materials 9,9-bis[4-(2-hydroxyethoxy)phenyl]fluorene- terephtalic acid-ethylene glycol copolymer (OPET), polyvinilbutyral (PVB), or polycarbonate-Z (PC-Z) - were coated on the polyethylene-theraphthalate (PET) film covered by $\mathrm{Al}$ and barrier layers, and the $7-8 \mu \mathrm{m}$ thick layers were formed. The influence of HTM, ETM, and various binding polymer compositions to mobility of electrons and holes has been investigated. The variation of composition of layers changes the mean hopping distance, the relational values of which for electrons and holes, respectively, has been evaluated by blend weight ratio:

$$
d_{\mathrm{p}} \sim \sqrt[3]{\frac{(\mathrm{ETM})+(\mathrm{HTM})+(\mathrm{BM})}{(\mathrm{HTM})}}
$$

and

$$
d_{\mathrm{n}} \sim \sqrt[3]{\frac{(\mathrm{ETM})+(\mathrm{HTM})+(\mathrm{BM})}{(\mathrm{ETM})}} .
$$

The mobility of charge carriers was measured using time-of-flight (TOF) method. For TOF measurements the semitransparent $3 \mathrm{~mm}$ diameter Al layer was evaporated onto the top of structure. After the $U=0-600 \mathrm{~V}$ voltage was applied onto the $\mathrm{Al}$ top electrode, the delayed by $t_{\mathrm{d}}$ pulse of ultraviolet light (Nichia UV LED NSHU 590) creates charge carrier pairs at the surface of layer. If positive potential is applied onto the il- 


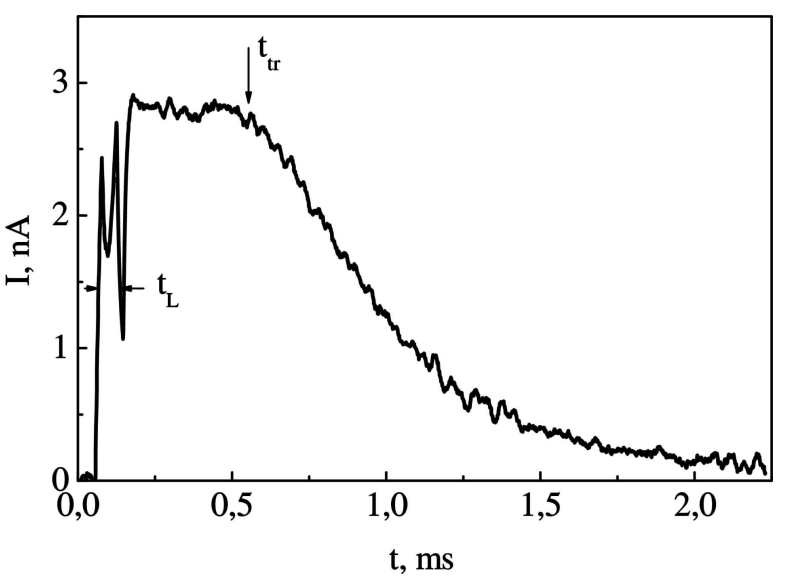

Fig. 1. Typical TOF photocurrent transient. $t_{\mathrm{L}}-\mathrm{UV}$ light pulse, $t_{\mathrm{tr}}$ - transit time.

luminated electrode, the holes drift to the opposite electrode. The typical photocurrent transient is shown in Fig. 1. From the kink of current transient the transit time $\left(t_{\mathrm{tr}}=d^{2} /(\mu U)\right)$ was obtained and the drift mobility of holes was estimated. The influence of $t_{\mathrm{d}}$ on $t_{\mathrm{tr}}$ was checked and assured that, after the voltage was applied on sample, the redistribution of electric field due to extraction of equilibrium charge carriers or injection from electrodes was absent. To escape possible electric noises the temperature of sample was adjusted by vapour of liquid nitrogen or hot air.

Because the electron mobility is by two orders of magnitude smaller than that of holes, it has been measured using the xerographic TOF (XTOF) method.

According to widely used disorder formalism of charge carrier transport in organic materials, charge carrier mobility is described as follows [3]:

$$
\begin{aligned}
\mu(F, T)= & \mu_{0} \exp \left(-\frac{2 \sigma}{3 k T}\right)^{2} \\
& \times \exp \left\{C\left[\left(\frac{\sigma}{k T}\right)^{2}-\Sigma^{2}\right] \sqrt{F}\right\} .
\end{aligned}
$$

Here $\sigma$ describes splitting of localized states in energy, and is equal to halfwidth of Gaussian energetic distribution of density of states; $\Sigma$ is parameter describing positional disorder of distribution of localized states; $C$ is empiric constant, which weakly depends on density of states and is approximately equal to $2.9 \cdot 10^{-4}(\mathrm{~cm} / \mathrm{V})^{0.5}$. This formula gives good description of charge carrier mobility of organic materials in the $10^{5}-10^{6} \mathrm{~V} / \mathrm{cm}$ electric field region, and in $T_{\mathrm{c}}<T<T_{\mathrm{g}}$ temperature interval (here $T_{\mathrm{c}}$ corresponds to temperature where charge carrier transport becomes dispersive, i. e. in photocurrent transients disappears the kink of charge carrier transit time; $T_{\mathrm{g}}$ is

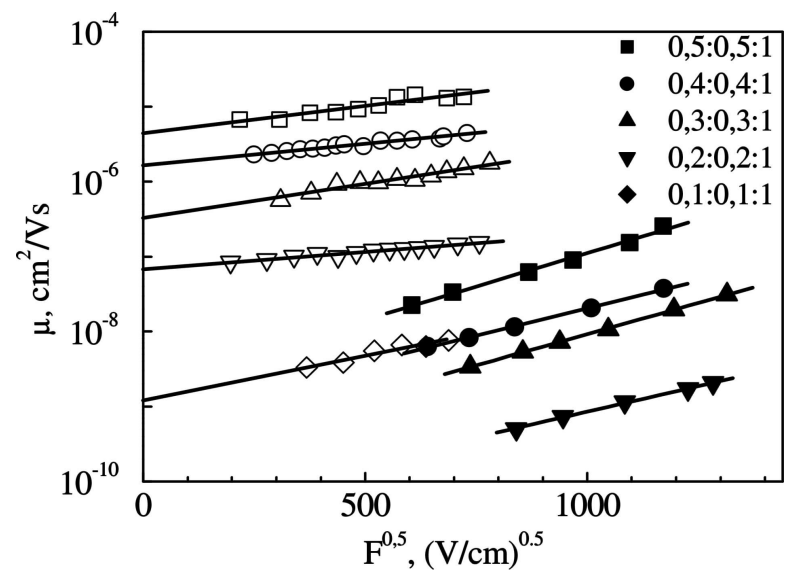

Fig. 2. Electric field dependence of hole and electron drift mobility for different compositions HTM : ETM : OPET (holes - open symbols, electrons - solid symbols).

glass temperature). The parameter $\sigma$ may be estimated from the plot. The $\Sigma$ is calculated from expression

$$
\beta=C\left[\left(\frac{\sigma}{k T}\right)^{2}-\Sigma^{2}\right]
$$

plotted as dependence on $1 /(\mathrm{kT})^{2}$, when it intersects with the temperature axis.

\section{Results and discussion}

In Fig. 2 the experimentally measured dependences of electron and hole mobility on electric field and on composition of layers are plotted in Poole-Frenkel description. The clear reduction of mobility of both electrons and holes with decrease of amount of corresponding transport material in the layer is seen. If experimental $\mu(F)$ dependences are extrapolated to $F=0$, the $\mu(0)$ values for each HTM (or ETM) density may be evaluated. The plot of $\mu(0)$ dependence on the relative mean distance between HTM molecules $\left(d_{\mathrm{p}} \sim C^{-1 / 3}\right.$, here $C=\mathrm{HTM} /(\mathrm{HTM}+\mathrm{ETM}+\mathrm{BM}))$ demonstrates reliance, which is typical of hopping transport description (Fig. 3):

$$
\mu \sim \exp \left(-2 \alpha d_{\mathrm{p}}\right)
$$

This also proves that both ETM and HTM distribute homogeneously, without clustering, in the bulk of layer. For comparison, the values of hole and electron mobility of pure, vacuum-deposited HTM and ETM are shown, respectively. These values nicely fit into Eq. 3 . From Fig. 3 the weak dependence of $\mu(0)$ on binding material is also seen: use of PVB gives smaller values than one gets in case of OPET binding material.

For evaluation of the influence of electron transport material on mobility of holes, there was made a 


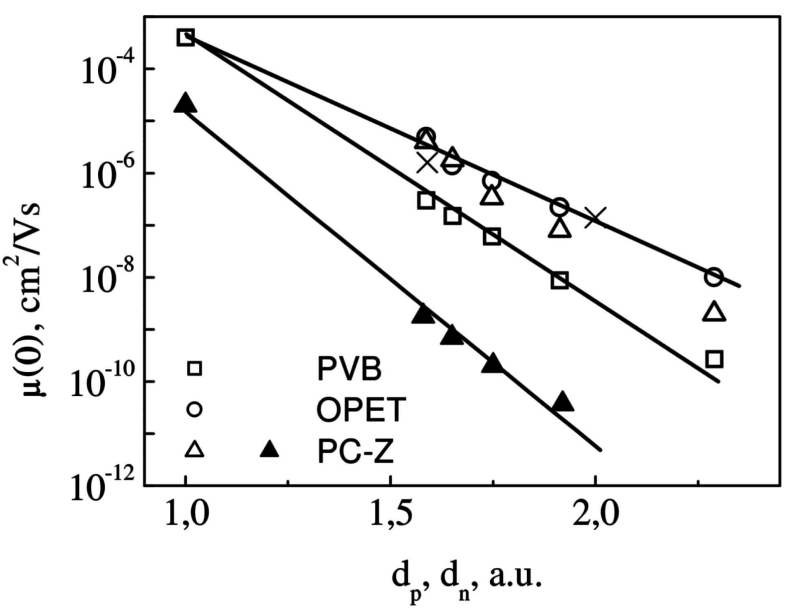

Fig. 3. Prefactor mobility $\mu(0)$ dependence on mean hopping distance for holes $d_{\mathrm{p}}$ and electrons $d_{\mathrm{n}}$ for layers with different binding polymers (holes - open symbols, electrons - solid symbols).

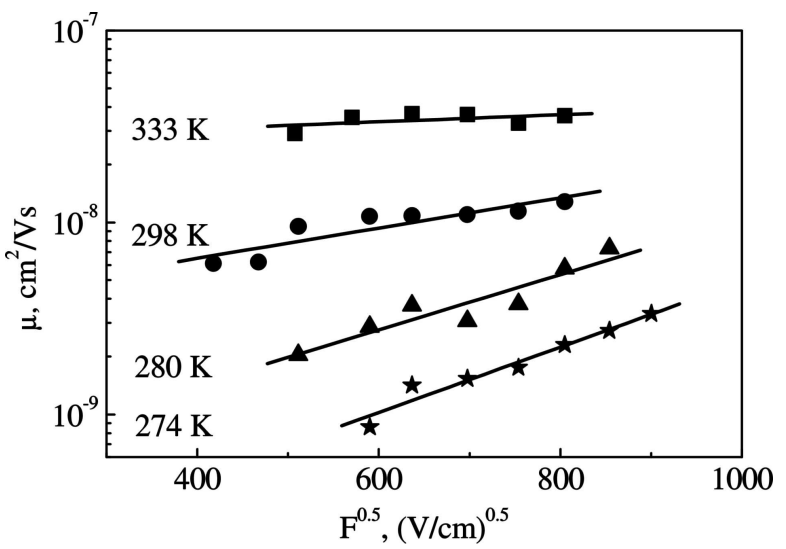

Fig. 4. Typical electric field dependence of hole mobility at different temperatures for HTM : ETM : OPET $(0.1: 0.1: 1)$ layer.

special group of samples, which consisted of mixtures of HTM and ETM materials of different HTM/ETM ratios. The $\mu(0)$ dependences on $d$ well fit Eq. 3 dependence (in Fig. 3 - mobility measurement results of layers of $0.2: 0.4: 1$ and $0.4: 0.2: 1$ compositions, marked by ' $x$ '). This shows that ETM does not influence transport of holes and, vice versa, HTM does not influence transport of electrons. The similar results have been observed in mixtures of PTS and TTA polyester [4]. Contrarily, in a mixture of PTS acceptor and TPD donor, the hole mobility is strongly influenced by acceptors due to formation of charge transfer (CT) complexes [5].

Figure 4 shows a typical dependence of hole mobility on electric field, measured at different temperatures. Obviously, $\mu$ does not depend on electric field at high temperatures, and for some samples it even decreases with increasing electric field. The $\sigma$ for samples with different compositions has been estimated from dependence of extrapolated mobility $\mu(E=0)$ on $1 / T^{2}$ (a

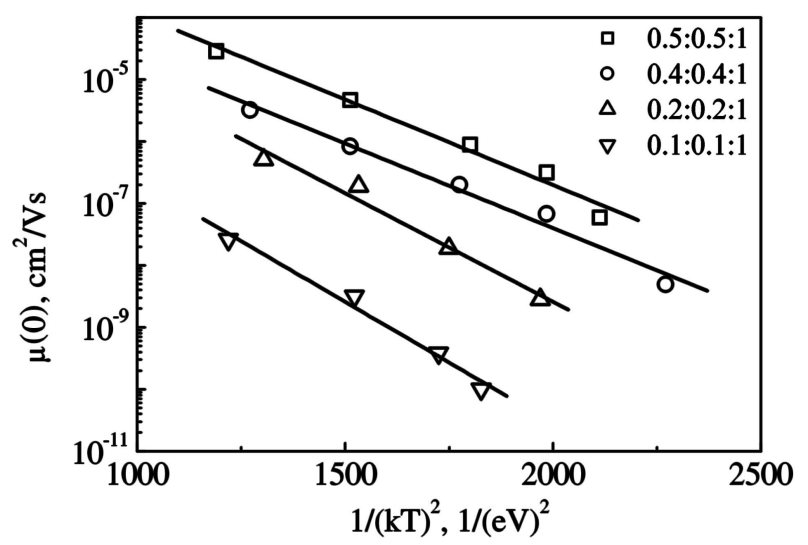

Fig. 5. Dependences of $\mu(0)$ of various composition samples with OPET on $1 /(k T)^{2}$.

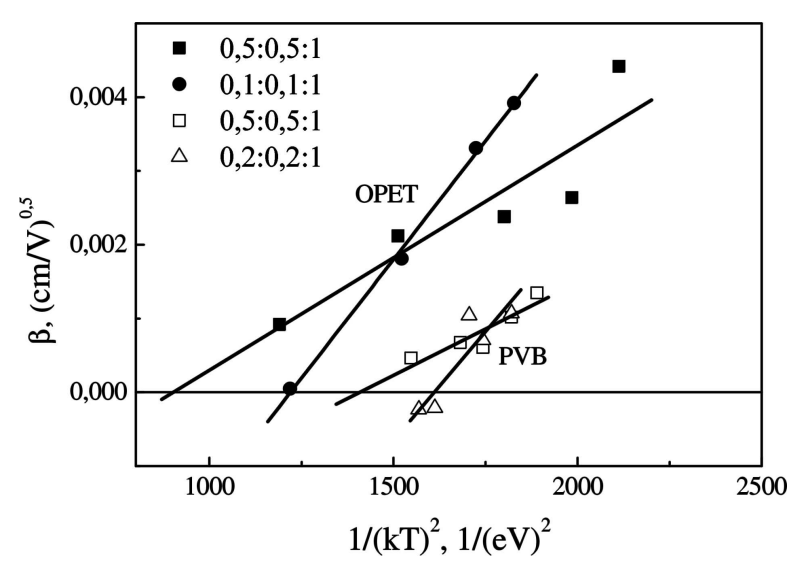

Fig. 6. Dependences of $\beta$ of various composition samples on $1 /(k T)^{2}$.

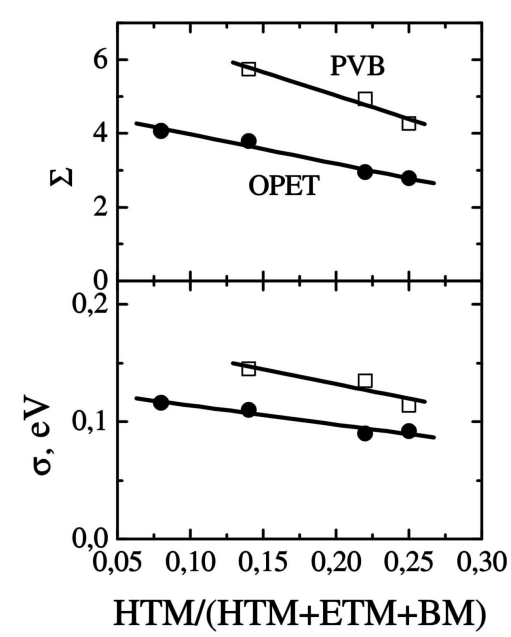

Fig. 7. Dependences of parameters $\sigma$ and $\Sigma$ on composition of samples.

typical dependence is shown in Fig. 5), and the spatial disorder parameter of localized states $\Sigma$ has been estimated from the slope coefficient $\beta \sim 1 / T^{2}$ (see Fig. 6).

The obtained results (Fig. 7) indicate that the 


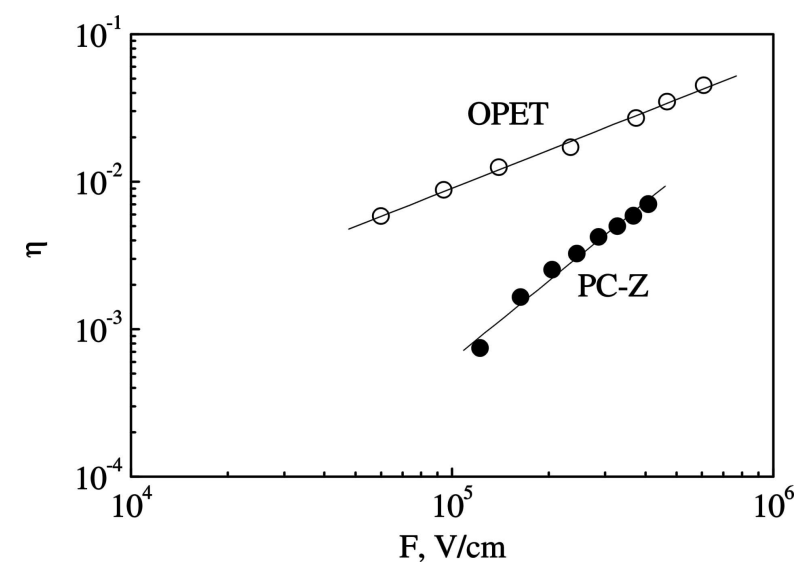

Fig. 8. Quantum efficiency dependences on electric field for different binding materials.

spatial disorder parameter $\Sigma$ grows faster than the energy state distribution parameter, when HTM concentration is decreased. This causes the decrease of mobility with increasing electric field strength at high temperatures. Values of $\Sigma$ are similar to reported values for the majority of doped polymers [4,5]. A similar growth of $\Sigma$ with decreasing concentration of HTM (PTS) was found in [4], although $\sigma$ did not depend on composition. However, a change of TPD concentration [5] causes a change of $\Sigma$ that is similar to the change of density of CT complexes, and the maximum of $\Sigma$ has been observed when concentrations of donor TPD and acceptor PTS are equal to each other. Positional disorder is attributed to packing constraints.

The results of investigation of photogeneration efficiency are shown in Fig. 8. The values of quantum yield $\eta$ are smaller than 1 , and dependence on electric field strength shows that there is no reduction of gemini recombination. It has been determined also that $\eta$ does not depend on ETM and HTM concentration, but strongly depends on the binding polymer, indicating the role of the latter in separating a photogenerated pair of charge carriers.

\section{Conclusions}

In blends of hole and electron transporting materials bounded with different polymers the mobility of holes and electrons depends on the distance between the transporting molecules exponentially. The binding material and electron transporting material only weakly influence the mobility. Interpretation of hole mobility dependences on electric field and temperature by the disorder formalism demonstrates that in blend layers with decreasing density of HTM the parameter of energetic disorder of states increases very slightly, while the parameter of positional disorder significantly increases, causing the flattening of $\ln \mu \sim \sqrt{F}$ dependence. The quantum efficiency very slightly depends on the concentration of transport materials, but depends on binding materials.

\section{Acknowledgement}

We thank the Lithuanian State Science and Studies Foundation for financial support via the program No. T-105/2005.

\section{References}

[1] N.S. Sariciftci, L. Smilowitz, A.J. Heeger, and F. Wudl, Photoinduced electron transfer from a conducting polymer to buckminsterfullerene, Science 258, 1474-1476 (1992).

[2] A. Pivrikas, G. Juška, A.J. Mozer, M. Scharber, K. Arlauskas, N.S. Sariciftci, H. Stubb, and R. Österbacka, Bimolecular recombination coefficient as a sensitive testing parameter for low-mobility solar-cell materials, Phys. Rev. Lett. 94, 176806 (2005).

[3] H. Baessler, Charge transport in disordered organic photoconductors, Phys. Status Solidi B 175, 15-56 (1993).

[4] W.T. Gruenbaum, E.H. Magin, and P.M. Borsenberger, Bipolar transport in molecularly doped polymers, J. Imaging Sci. Technol. 40, 310-317 (1996).

[5] A. Schreiber, S.J. Zilker, and D. Haarer, Correlation between charge-transfer complex formation and positional disorder in a binary donor-acceptor glass, J. Chem. Phys. 112, 7190-7194 (2000). 


\title{
BIPOLINĖ KRŪVININKŲ PERNAŠA ORGANINIŲ MEDŽIAGŲ MIŠINIUOSE
}

\author{
G. Juška, E. Montrimas, J. Sidaravičius, G. Sliaužys
}

Vilniaus universitetas, Vilnius, Lietuva

\section{Santrauka}

Lèkio trukmès metodu buvo tiriama skylių ir elektronų pernaša mišiniuose iš donorinių ir akceptorinių organinių molekulių, surištų skirtingomis polimerinėmis medžiagomis. Išmatuotos elektronų ir skyliu judrių priklausomybės nuo elektrinio lauko stiprio, temperatūros ir sudèties. Remiantis krūvininku pernašos netvarkiuose organinių medžiagų dariniuose aprašymu, îvertinti būsenų energinės ir erdvinès netvarkos parametrai. 